\title{
Protective effect of drugs on histamine-induced asthma
}

\author{
DONALD W. COCKCROFT, DERMOT N. KILLIAN, J. J. ADRIAN MELLON, AND \\ FREDERICK E. HARGREAVE
}

From the Department of Medicine, McMaster University and St. Joseph's Hospital, Hamilton, Ontario, Canada

Cockcroft, D. W., Killian, D. N., Mellon, J. J. A., and Hargreave, F. E. (1977). Thorax, 32, 429-437. Protective effect of drugs on histamine-induced asthma. Controlled standardised histamine inhalation tests were carried out in 21 asthmatics to determine the degree of nonspecific bronchial hyperreactivity with and without prior treatment with several anti-asthmatic drugs. A significant protective effect was produced by inhaled salbutamol, $200 \mu \mathrm{g}$, ingested salbutamol, $4 \mathrm{mg}$, inhaled Sch1000, $40 \mu \mathrm{g}$, inhaled atropine sulphate, $290 \mu \mathrm{g}$, and ingested choline theophyllinate ( 200 or $400 \mathrm{mg}$ ) producing serum theophylline levels over $10 \mathrm{mg} / 1$. Inhaled salbutamol was consistently the most effective and was significantly better than the other drugs. The protective effect between the other four was not significantly different. Drug side-effects occurred only with the ingested drugs. No significant protection was detected after ingested choline theophyllinate producing serum theophylline levels of less than $10 \mathrm{mg} / \mathrm{l}$, inhaled sodium cromoglycate, $20 \mathrm{mg}$ given once or six-hourly for one week, or ingested ascorbic acid, 1 gram.

In most persons with asthma there is a nonspecific increase in the reactivity of the bronchial smooth muscle (Orehek and Gayrard, 1976). This increased reactivity can be demonstrated in the laboratory by inhalation of histamine (Curry, 1946; Makino, 1966; Laitinen, 1974). Histamine, in low concentrations, is thought to act chiefly as an irritant (Sellick and Widdicombe, 1971), although it may also exert a direct effect on bronchial smooth muscle (Altounyan, 1971). Naturally occurring irritants such as dust (Sellick and Widdicombe, 1971), smoke (Simonsson et al., 1967), and cold air (Wells et al., 1960) are important triggers of asthma (Lancet, 1975). The avoidance of them and protection against their effects by drugs are important aspects of treatment.

In this study we have examined and compared the protective effect of recommended therapeutic doses of a number of drugs on histamine-induced bronchoconstriction, including salbutamol, atropine sulphate, Sch1000, sodium cromoglycate, choline theophyllinate, and ascorbic acid.

\section{Methods}

Twenty-one patients with asthma (Ciba Founda- tion Guest Symposium, 1959) of varying severity were selected from the Chest and Allergy Clinic at St. Joseph's Hospital, Hamilton (Table 1). All had airways obstruction reversible by bronchodilators and/or corticosteroids. At the time of study the forced expired volume in one second $\left(\mathrm{FEV}_{1}\right)$ was between 57 and $97 \%$ (mean $84 \% \pm$ $11 \mathrm{SD}$ ) of the patient's previous best values. All had been noted to have a raised total blood eosinophil count of over $400 / \mathrm{mm}^{3}$ and/or an increase in sputum eosinophils. Thirteen of the patients were considered atopic, having evidence from history and skin tests of allergic factors. The skin tests were carried out by the modified prick technique using 16 common allergen extracts. There were no other complicating respiratory diseases. Informed consent was obtained. All of the patients understood that they were to be given a series of histamine inhalation tests and certain medicines currently in use for the treatment of asthma, but they did not know the nature of the medicines.

The standard histamine inhalation test was performed in the following way. $\mathrm{FEV}_{1}$ was measured in triplicate with a Collins' 14-litre water spirometer. Five millilitres of the test solution was 
Table 1 Patient data

\begin{tabular}{|c|c|c|c|c|c|c|c|c|c|c|c|c|c|c|c|c|}
\hline \multirow[b]{2}{*}{ No. } & \multirow[b]{2}{*}{ Age } & \multirow[b]{2}{*}{$\operatorname{Sex}$} & \multirow[b]{2}{*}{ Atopy } & \multicolumn{2}{|l|}{ Treatment } & \multirow{2}{*}{$\begin{array}{l}F E V_{1} \\
\text { (litres) }\end{array}$} & \multirow{2}{*}{$\begin{array}{l}\text { Threshold } \\
\text { HAP } \\
\text { concentration } \\
(\mathrm{mg} / \mathrm{ml})\end{array}$} & \multicolumn{9}{|c|}{ Drugs investigated } \\
\hline & & & & $\begin{array}{l}\text { Regular } \\
\text { broncho- } \\
\text { dilators }\end{array}$ & Others & & & $S i$ & So & $S C H$ & $A S$ & $C T>10$ & $C T<10$ & $S C G$ & $S C G_{7}$ & $A A$ \\
\hline 1 & 28 & $\mathbf{M}$ & + & & & $3 \cdot 5$ & 4 & + & + & + & + & & + & + & & + \\
\hline 2 & 35 & $\mathbf{F}$ & + & & & $2 \cdot 4$ & 4 & & & & & & & + & + & \\
\hline 3 & 40 & $\mathbf{M}$ & & & & $3 \cdot 7$ & 2 & + & & + & + & & & + & & \\
\hline 4 & 21 & F & + & & & $2 \cdot 6$ & 2 & & & & & & + & & & \\
\hline 5 & 36 & F & & $\div$ & B400 & $2 \cdot 8$ & 2 & & & & & + & & & & \\
\hline 6 & 31 & $F$ & & + & P15 & $1 \cdot 6$ & 1 & + & + & & & & & + & & \\
\hline 7 & 29 & $\mathbf{F}$ & + & & & $2 \cdot 6$ & 1 & + & & & & & & & & + \\
\hline 8 & 27 & $F$ & + & $\therefore$ & B400 & $3 \cdot 1$ & 0.5 & + & & + & $\div$ & & + & & & + \\
\hline 9 & 49 & $\mathbf{F}$ & & & & $2 \cdot 4$ & 0.5 & & & & & & & + & + & \\
\hline 10 & 35 & $\mathbf{F}$ & & + & P10 & $2 \cdot 6$ & 0.5 & + & + & + & + & & + & + & & + \\
\hline 11 & 46 & $\mathbf{M}$ & & + & P10 & $2 \cdot 5$ & 0.5 & + & + & & + & & & + & & \\
\hline 12 & 50 & F & + & + & B 100 & $1 \cdot 7$ & 0.25 & & & & & + & + & & & \\
\hline 13 & 19 & F & + & + & P10 & $2 \cdot 2$ & 0.25 & + & + & & + & & & + & & \\
\hline 14 & 51 & $\mathbf{F}$ & + & + & SCG & $1 \cdot 7$ & 0.25 & + & & + & + & & & & & \\
\hline 15 & 22 & $\mathbf{M}$ & + & + & B400 & $2 \cdot 3$ & 0.25 & + & + & & & $t$ & + & & & \\
\hline 16 & 28 & $\mathbf{M}$ & + & + & & $2 \cdot 8$ & 0.25 & & & & & & + & & & \\
\hline 17 & 26 & $F$ & + & $\therefore-$ & & $3 \cdot 2$ & 0.125 & & & & & & & + & + & \\
\hline 18 & 29 & $\mathbf{M}$ & + & & & $2 \cdot 0$ & 0.125 & + & + & + & & + & + & & & \\
\hline 19 & 23 & $\mathbf{M}$ & + &.+ & & $3 \cdot 1$ & 0.125 & + & + & & & & + & & & \\
\hline 20 & 46 & $\mathbf{F}$ & & + & P25 & $1 \cdot 2$ & 0.063 & + & + & + & + & + & & + & & \\
\hline 21 & 58 & $\mathbf{F}$ & & + & B200 & $1 \cdot 0$ & 0.031 & & & & & + & & & & \\
\hline
\end{tabular}

Abbreviations: $\mathbf{P}=$ prednisone $(\mathrm{mg} / \mathrm{day}), \mathrm{B}=$ beclomethasone $(\mu \mathrm{g} / \mathrm{day}), \mathrm{SCG}=$ sodium cromoglycate, $\mathrm{Si}=\mathrm{inhaled}$ salbutamol, $\mathrm{So}=$ oral salbutamol, $\mathrm{SCH}=\mathrm{Sch} 1000, \mathrm{AS}=$ atropine sulphate, $\mathrm{CT}>10=$ choline theophyllinate with serum theophylline levels $>10 \mathrm{mg} / \mathrm{l}, \mathrm{CT}<10=$ choline theophyllinate with serum theophylline levels $<10 \mathrm{mg} / \mathrm{l}, \mathrm{SCG}_{7}=$ sodium cromoglycate for one week, $\mathrm{AA}=$ ascorbic acid.

placed in a Wright nebuliser and an aerosol was generated with an oxygen flow of 7 litres per minute (particle size $-1 \cdot 3 \mu$ mass median diameter; nebuliser output $0.13 \mathrm{ml} / \mathrm{min}$ ). A nose clip was applied and the subject inhaled the aerosol via a face mask by quiet tidal breathing for 2 minutes. $\mathrm{FEV}_{1}$ was repeated 30 and 90 seconds after completion of the inhalation. The first solution inhaled was phosphate buffered saline as a control. This was followed, at 5-minute intervals, by inhalation of successively doubled concentrations of histamine acid phosphate (HAP) $(0.03,0.06,0.125$, $0.25,0.5,1,2,4$, and $8 \mathrm{mg} / \mathrm{ml}$ ) until a fall in FEV $_{1}$ of $20 \%$ was produced or until the maximum concentration of $8 \mathrm{mg} / \mathrm{ml}$ was reached. $F_{1} V_{1}$ was then also repeated at 3 and 5 minutes. The percentage fall in $\mathrm{FEV}_{1}$ was calculated from the lowest post-saline $\mathrm{FEV}_{1}(\mathrm{FEV} \mathrm{s})$ and the lowest post-HAP $\mathrm{FEV}_{1}\left(\mathrm{FEV}_{\mathrm{H}}\right)$ by the formula:

$$
100 \times\left(\text { FEV } s-\text { FEV }_{\text {H }}\right) / \text { FEV s }
$$

The lowest concentration of HAP which produced a greater than $20 \%$ fall in $\mathrm{FEV}_{1}$ was termed the threshold concentration. When the test is performed in this way the step up in dose at 5-minute intervals does not produce a cumulative effect or tolerance, so that if the test is repeated using only the threshold concentration the response is the same (Cockcroft et al., in preparation).

Patients were studied on three or more days at the same time of day within a two-week period.
On the first day, a standard histamine inhalation test was performed as outlined above. On subsequent day(s) patients were pretreated with a test drug (Table 1). After an interval, chosen to coincide with the time of maximum effect of the test drug (Table 2), the histamine inhalation test was repeated, omitting the saline inhalation and starting with the threshold HAP concentration identified on the first day. On the final day the test was repeated with no test drug, to check that the response was similar to that of the first day. On the second and all subsequent days the fall in $\mathrm{FEV}_{1}$ was calculated from the lowest initial and lowest post-HAP values.

Table 2 Drugs investigated

\begin{tabular}{|c|c|c|c|}
\hline Drug & Dose & $\begin{array}{l}\text { Route of } \\
\text { administration }\end{array}$ & $\begin{array}{l}\text { Interval } \\
\text { before } \\
\text { test } \\
\text { (min) }\end{array}$ \\
\hline Salbutamol & $200 \mu \mathrm{g}$ & Inhaled ${ }^{1}$ & 15 \\
\hline Salbutamol & $4 \mathrm{mg}$ & Oral & 60 \\
\hline Sch 1000 & $40 \mu \mathrm{g}$ & Inhaled $^{1}$ & 60 \\
\hline Atropine sulphate & $290 \mu \mathrm{g}$ & Inhaled ${ }^{2}$ & 60 \\
\hline Choline theophyllinate & $200-400 \mathrm{mg}$ & Oral & 180 \\
\hline \multirow[t]{2}{*}{ Sodium cromoglycate } & $20 \mathrm{mg}$ & Inhaled $^{3}$ & 15 \\
\hline & $20 \mathrm{mg}$ qid 7 days & Inhaled ${ }^{3}$ & 15 \\
\hline Ascorbic acid & $1 \mathrm{~g}$ & Oral & 60 \\
\hline
\end{tabular}

'Two puffs from a meterised canister.

${ }^{2}$ Atropine sulphate $0.2 \%$ nebulised in Wright nebuliser by oxygen flow $71 / \mathrm{min}$ and inhaled for 1 minute by tidal breathing. Spinhaler. 
Throughout the study an attempt was made to control factors known, or thought, to influence the level of non-specific bronchial reactivity. None of the patients smoked, none had evidence of recent respiratory infection, and none was exposed to relevant allergens. In all patients the initial $\mathrm{FEV}_{1}$ was within $20 \%$ of that on the first day; in 18 of the 21 it was within $10 \%$. The use of other anti-asthmatic drugs was carefully controlled. Salbutamol and sodium cromoglycate were withheld for 6 hours and choline theophyllinate for 24 hours. Corticosteroids were continued in the same dose.

Serum theophylline levels were measured by a modified method of Schack and Waxler (1949) on days when the effect of choline theophyllinate was under study. On these days the blood sample was obtained immediately before histamine challenge.

In an analysis of the results, bronchial reactivity was expressed as the HAP provocation concentration required to produce a $20 \% \mathrm{FEV}_{1}$ fall $\left(\mathrm{PC}_{20}\right)$. The $\mathrm{PC}_{20}$ was calculated from the histamine doseresponse curve or, in subjects in whom a single HAP concentration produced more than a $20 \%$ $\mathrm{FEV}_{1}$ fall, from the formula:

$\mathrm{PC}_{20}=20 \% \times$ HAP concentration $/ \%$ fall in $\mathrm{FEV}_{1}$ The $\mathrm{PC}_{20}$ in normal subjects, using the same method of histamine inhalation, is usually $>8 \mathrm{mg} / \mathrm{ml}$ (Cockcroft et al., in preparation). Reproducibility of the first and final control tests was assessed by calculation of the coefficient of variation:

$100 \times \mathrm{SD}$ of difference between two tests/ $\sqrt{2 \times}$ mean value of test result

Protection against histamine-induced asthma was indicated by a rise in $\mathbf{P C}_{20}$ above that observed on either control day. Geometric means and SD for $\mathrm{PC}_{20}$ were calculated using logarithmic transformation. They were compared for significance using the paired or unpaired Student's $t$ test where appropriate. Linear regression analysis was done by the method of least squares. Differences were considered significant if $\mathbf{P}<0.05$.

\section{Results}

The first and final (control) histamine inhalation tests showed, for the same inhaled HAP concentration, a difference in the percentage $\mathrm{FEV}_{1}$ fall of 0 to 18 , mean $5.5 \%$, coefficient of variation $15 \%$.

Significant bronchodilatation was seen after salbutamol, Sch1000, atropine sulphate, and choline theophyllinate, producing serum theophylline levels over $10 \mathrm{mg} / 1$ (Table 3 ). Inhaled salbutamol was the most effective and in paired samples was superior to ingested salbutamol $(n=9$, $\mathrm{P}<0.05)$ and to atropine sulphate $(\mathrm{n}=8, \mathrm{P}<0.05)$ but not to $\operatorname{Sch} 1000(n=7, p<0 \cdot 20)$. No significant bronchodilatation was seen after sodium cromoglycate, ascorbic acid, or choline theophyllinate producing serum theophylline levels less than $10 \mathrm{mg} / 1$.

Significant protection against histamine-induced asthma was observed after inhaled and ingested salbutamol, Sch1000, atropine sulphate, and choline theophyllinate with serum theophylline levels over $10 \mathrm{mg} / 1$ (Fig. 1; Table 3). No protection was seen after sodium cromoglycate, ascorbic acid, or choline theophyllinate with serum theophylline levels under $10 \mathrm{mg} / 1$.

Inhaled salbutamol was the most effective drug in protecting against histamine-induced asthma in all 13 subjects receiving it. This is illustrated by comparative dose-response curves from a repre-

Table 3 Comparative drug protection in histamine-induced asthma

\begin{tabular}{|c|c|c|c|c|c|c|c|c|c|}
\hline \multirow{3}{*}{ Drug } & \multirow{3}{*}{$\begin{array}{l}\text { No. of } \\
\text { patients } \\
\text { tested }\end{array}$} & \multirow{2}{*}{\multicolumn{3}{|c|}{$\begin{array}{l}\text { Bronchodilatation } \\
F E V_{1}\end{array}$}} & \multicolumn{5}{|c|}{ Improvement in bronchial reactivity } \\
\hline & & & & & \multicolumn{2}{|c|}{ Patients improved } & \multicolumn{3}{|c|}{ Histamine provocation concentration $\left(P C_{20}\right)$} \\
\hline & & $\begin{array}{l}\text { Mean \% } \\
\text { increase }\end{array}$ & $S D$ & $\mathbf{P}$ & No. & $\%$ & $\begin{array}{l}\text { Control } P C_{20} \\
\text { geometric } \\
\text { mean }(\mathrm{mg} / \mathrm{ml})\end{array}$ & $\begin{array}{l}\text { Treated } P C_{20} \\
\text { geometric } \\
\text { mean }(\mathrm{mg} / \mathrm{ml})\end{array}$ & $\begin{array}{l}\text { Significance } \\
\text { of difference }\end{array}$ \\
\hline $\begin{array}{l}\text { Si } \\
\text { So } \\
\text { SCH } \\
\text { AS } \\
\text { CT }<10 \\
\text { CT >10 } \\
\text { SCG } \\
\text { SCG, } \\
\text { AA }\end{array}$ & $\begin{array}{r}13 \\
9 \\
7 \\
8 \\
6 \\
9 \\
10 \\
3 \\
4\end{array}$ & $\begin{array}{c}13 \cdot 0 \\
6 \cdot 7 \\
10 \cdot 7 \\
6 \cdot 0 \\
11 \cdot 3 \\
2 \cdot 9 \\
0 \\
0 \\
2 \cdot 0\end{array}$ & $\begin{array}{l}8 \cdot 5 \\
7 \cdot 3 \\
7 \cdot 6 \\
4 \cdot 9 \\
7 \cdot 6 \\
4 \cdot 3 \\
3 \cdot 6 \\
\overline{2 \cdot 5}\end{array}$ & $\begin{array}{l}<0.001 \\
<0.05 \\
<0.02 \\
<0.02 \\
<0.05 \\
>0.10 \\
>0.20 \\
>0.20 \\
>0.20\end{array}$ & $\begin{array}{r}13 \\
5 \\
5 \\
6 \\
4 \\
2 \\
2 \\
0 \\
0\end{array}$ & $\begin{array}{r}100 \\
56 \\
71 \\
75 \\
67 \\
22 \\
20 \\
0 \\
0\end{array}$ & $\begin{array}{l}0.33 \\
0.21 \\
0.28 \\
0.28 \\
0.12 \\
0.30 \\
0.46 \\
0.42 \\
0.73\end{array}$ & $\begin{array}{l}3.99 \\
0.44 \\
0.78 \\
0.65 \\
0.26 \\
0.39 \\
0.51 \\
0.44 \\
0.73\end{array}$ & $\begin{array}{l}P<0.001 \\
P<0.02 \\
P<0.05 \\
P<0.01 \\
P<0.05 \\
P>0.1 \\
P>0.2 \\
P>0.2 \\
P>0.2\end{array}$ \\
\hline
\end{tabular}

Abbreviations as in Table 1. 


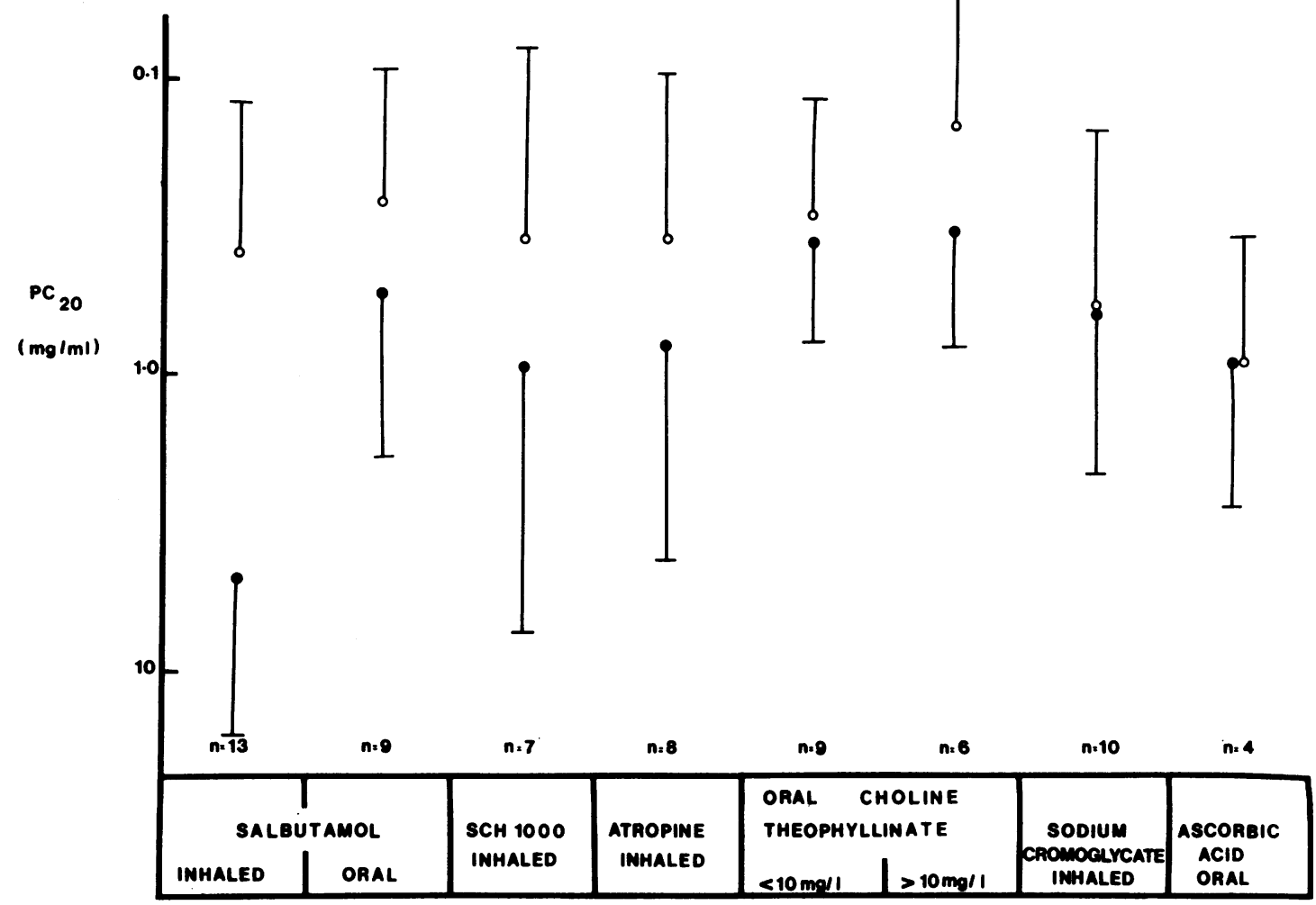

Fig. 1 Geometric mean $P C_{20}(\mathrm{mg} / \mathrm{ml})$. Open circles represent control values, closed circles represent values after administration of noted drugs, and vertical bars represent one geometric standard deviation.

sentative sample of subjects in Figures 2 and 3. After the inhalation of salbutamol, the geometric mean $\mathrm{PC}_{20}$ increased 12-fold over that in the two control tests. This compares with the 2- to 3-fold increases seen for the other four effective drugs (Table 3). A comparison of protective effect using paired samples showed that inhaled salbutamol provided significantly greater protection against histamine-induced asthma than did ingested salbutamol $(n=9, P<0.01)$, atropine sulphate $(n=8$, $P<0.01)$ or $\operatorname{Sch} 1000(n=7, P<0.05)$. In an unpaired comparison, inhaled salbutamol provided significantly greater protection than choline theophyllinate with serum theophylline levels $>10 \mathrm{mg} / 1\left(\mathrm{n}_{1}+\mathrm{n}_{2}=19, \mathrm{P}<0.001\right)$. There was no significant difference in the effect of ingested salbutamol, atropine, Sch1000, or choline theophyllinate.

The relationship of the degree of protection against histamine-induced asthma and the degree of bronchodilatation produced by the test drug was examined. Six of 18 patients who received bronchodilators had no bronchodilatation, yet they demonstrated a similar degree of protection against histamine-induced asthma. There was no correlation, for any drug, between the degree of bronchodilatation (\% improvement in $\left.\mathrm{FEV}_{1}\right)$ and the degree of protection (log change in $\mathrm{PC}_{20}$ ) $(0<\mathrm{r}<0.2, \mathrm{P}>0 \cdot 1)$.

Drug-induced side-effects were noted by seven patients. These included tremulousness after $4 \mathrm{mg}$ ingested salbutamol in two of nine patients $(22 \%)$, and anorexia, nausea, and/or headache after $400 \mathrm{mg}$ oral choline theophyllinate (two with serum theophylline under $10 \mathrm{mg} / \mathrm{l}$ ) in five of 12 patients $(42 \%)$.

Serum theophylline levels over $10 \mathrm{mg} / 1$ (mean $13.3 \pm 3.4 \mathrm{SD})$ were achieved in four subjects after $400 \mathrm{mg}$ choline theophyllinate and in two after $200 \mathrm{mg}$. Levels of under $10 \mathrm{mg} / 1$ (mean 


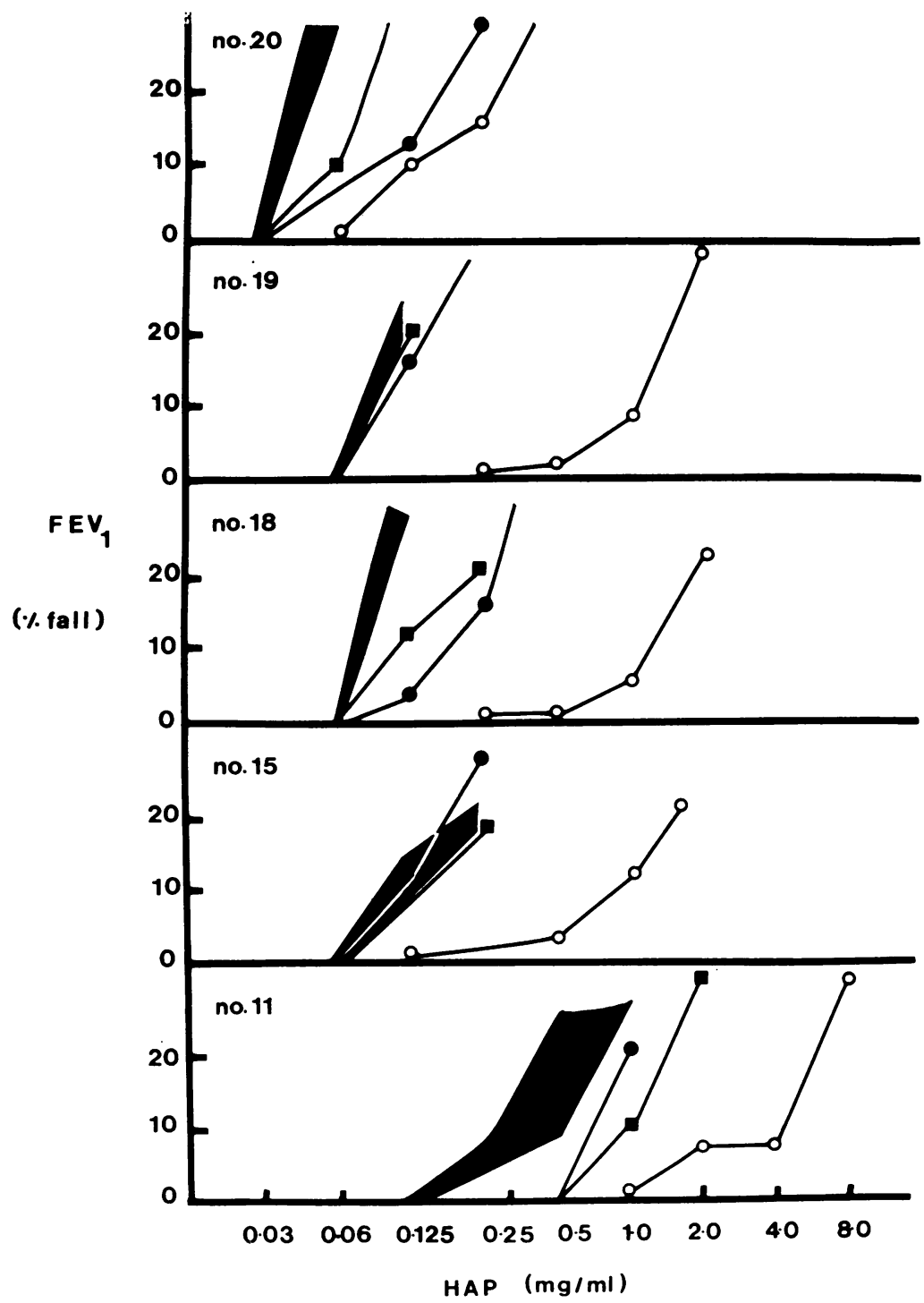

Fig. 2 Comparative protective effect of inhaled and ingested salbutamol and ingested choline theophyllinate in five representative subjects. Shaded area-control range; open circles-inhaled salbutamol; closed circlesingested salbutamol; squares-choline theophyllinate (serum theophylline levels; patient $20,17 \mathrm{mg} / \mathrm{l}$; patient $19,5 \mathrm{mg} / \mathrm{l}$; patient $18,12 \cdot 6 \mathrm{mg} / \mathrm{l}$; patient $15,6 \mathrm{mg} / \mathrm{l}$; and patient 11 , not determined). 


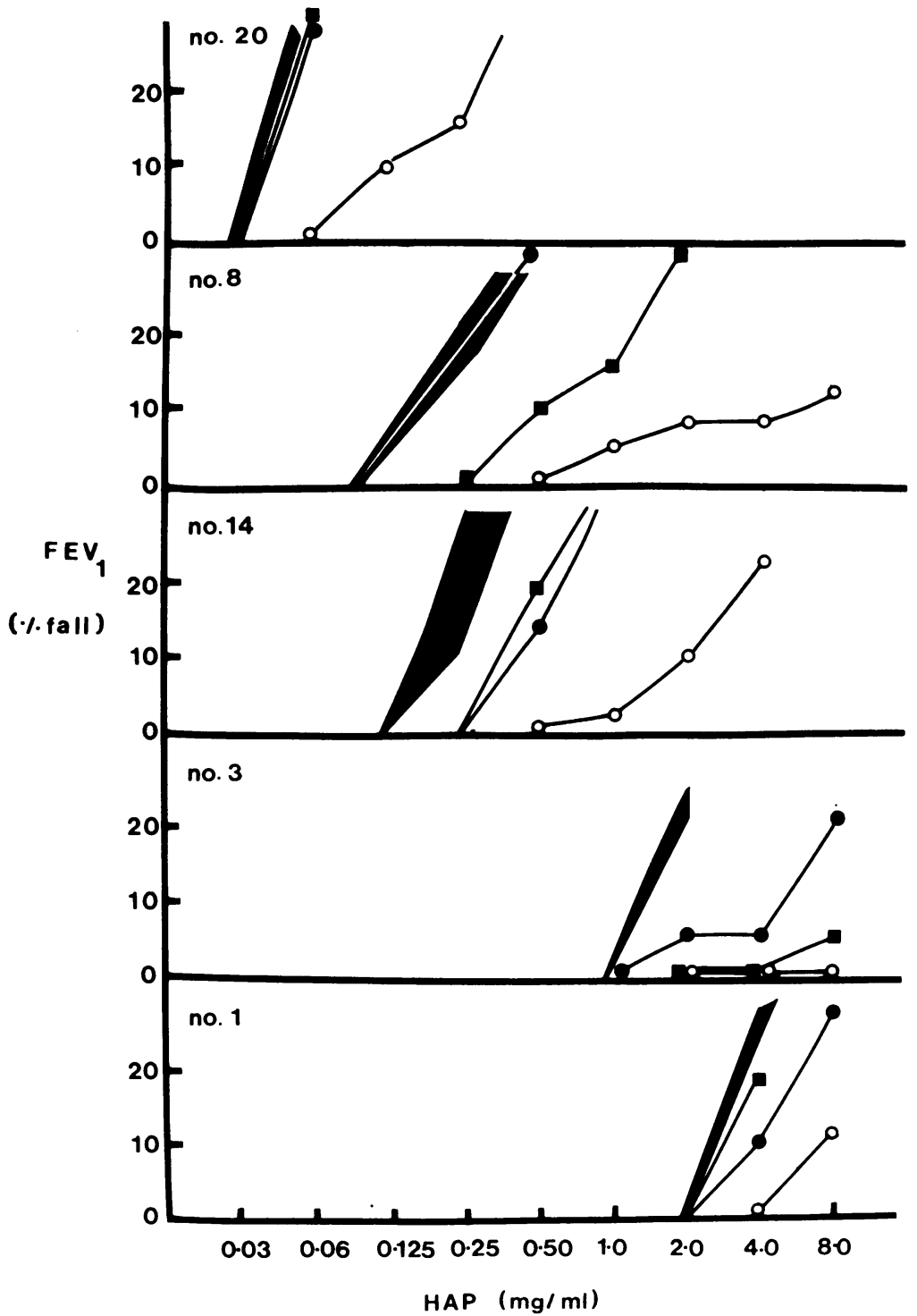

Fig. 3 Comparative protective effect of inhaled salbutamol, Sch1000, and atropine sulphate in five representative subjects. Shaded area-control range; open circles-salbutamol; closed circles-atropine sulphate; squaresSch1000. 
6.8 $\pm 1.6 \mathrm{SD})$ were seen after $400 \mathrm{mg}$ choline theophyllinate in four subjects and after $200 \mathrm{mg}$ in five.

\section{Disaussion}

The present study has examined the protective effect of a number of drugs on histamine-induced asthma. Protection was provided by salbutamol, Sch 1000 , atropine sulphate, and choline theophyllinate producing serum theophylline levels above $10 \mathrm{mg} / 1$. Inhaled salbutamol was the most effective; there was no difference between the protective effect of the others, including ingested salbutamol. No protection was provided by choline theophyllinate giving serum theophylline levels less than $10 \mathrm{mg} / 1$, sodium cromoglycate, and ascorbic acid.

Each drug was used in the recommended therapeutic dose which probably produces a maximum or near maximum effect, and was tested at a time regarded as optimal. No attempt was made to examine the effect of the drugs in different doses, except with choline theophyllinate, or at different times. It would have been preferable to include placebos for the inhaled and ingested drugs and to have tested each drug in each patient. However, there was, in most instances, administration of a drug which had no effect which could be taken to represent a placebo, and the study was single-blind. The patient was unaware of the nature of the drug and the dose of histamine administered. The histamine inhalation test, as carried out in this study, was reproducible in each patient over the test period as shown by comparison between first and final tests.

One factor contributing to the protective effect of the different drugs on histamine-induced asthma is their bronchodilating effect. It is well known that as airway, calibre increases the response to inhaled histamine decreases (Benson, 1975). In the present study, the drug producing the greatest bronchodilatation also produced the greatest protection. However, there is also clearly another factor independent of the degree of bronchodilatation. Thus Sch1000 produced as good bronchodilatation as inhaled salbutamol but gave less protection. Six subjects had no bronchodilatation following bronchodilator but had equal protection to those exhibiting bronchodilatation. Within the groups of patients tested with each drug no significant relationship was observed between the degree of bronchodilatation and the degree of protection. Altounyan (1974) has also observed that maximum bronchodilatation pro- duced by atropine sulphate and maximum protection against carbacol-induced asthma do not coincide; maximum bronchodilatation occurs at one hour and maximum protection immediately.

Inhaled histamine is thought to act chiefly by stimulating irritant receptors (Sellick and Widdicombe, 1971), and in this study it was used as a model of irritant-induced asthma. In previous studies of histamine on irritant-induced asthma protection has been observed with isoprenaline (Dubois and Dautrebande, 1958; Wells et al., 1960; Harnett and Spector, 1976), atropine (Altounyan, 1964; Nadel et al., 1965), and Sch1000 (Harnett and Spector, 1976) but not with salbutamol or theophylline. The clinical use of isoprenaline is no longer recommended because of its beta-one cardiac stimulating effects and the short duration of action. The present study identifies inhaled salbutamol, or presumably similar selective betatwo stimulants like inhaled orciprenaline and terbutaline, as the most effective drugs in protecting against histamine-induced, and possibly irritant-induced asthma. Ingested theophylline is not recommended because it is effective only when it produces serum levels of greater than $10 \mathrm{mg} / 1$ and these are associated with a high incidence of side-effects.

Inhaled irritants act through irritant receptors (Fillenz and Woods, 1970; Mills et al., 1970) in central airways and a reflex arc in vagal parasympathetic fibres (Simonsson et al., 1967). Their effects are blocked by anticholinergics. In the present study the failure of histamine-induced asthma to be blocked most effectively by anticholinergics may mean that histamine is exerting its effect, at least partly, through other mechanisms (Altounyan, 1971). In one other study Harnett and Spector (1976) report that Sch1000 protects more effectively than isoprenaline against histamine-induced asthma. Altounyan (1964), however, found isoprenaline better than atropine.

The parasympathetic reflex mechanism involved in irritant-induced asthma also participates in allergen-induced asthma (AIA) and may play a role in exercise-induced asthma (EIA). In AIA the level of non-specific reactivity measured by histamine inhalation influences the response to allergen (Killian et al., 1976); AIA is triggered more easily as the level of hyperreactivity increases. In EIA hyperventilation stimulates irritant receptors (Simonsson et al., 1967). One would therefore expect drugs effective in irritantinduced asthma to be also effective in AIA and EIA, and this has been observed with betaadrenergic stimulants (Booij-Nord et al., 1972; 
Kershnar et al., 1976; Godfrey and König, 1976) and anticholinergics (Itkin and Anand, 1970; Kersten, 1974; Godfrey and König, 1976; Kershnar et al., 1976). Godfrey and König (1976) found that salbutamol was also the most effective drug in EIA. He noted that oral salbutamol was as effective as inhaled salbutamol but only two cases of the former were examined. However, recently Anderson et al. (1976) have shown inhaled salbutamol to be superior to oral salbutamol in preventing EIA and suggested that the mechanism of this was independent of the bronchodilating effect. The effect of atropine varies in both EIA (Godfrey and König, 1976) and AIA (Itkin and Anand, 1970; Rosenthal et al., 1974) and this probably reflects different degrees of involvement of the parasympathetic reflex in different patients.

The lack of effect of sodium cromoglycate on histamine-induced asthma has been recorded by others (Cox, 1967; Ryo et al., 1971; Townley et al., 1973). This contrasts with its effectiveness in EIA (McNeill et al., 1966; Kershnar et al., 1976; Kiechel et al., 1976) and AIA (Pepys et al., 1968). Its mode of action in EIA is unknown. Patel et al. (1976) have recently suggested that its effect is related to the phosphodiesterase inhibiting action identified by Lavin et al. (1976). If this action is significant, it should produce bronchodilatation and protection against irritant-induced asthma. Sodium cromoglycate is effective in AIA by preventing release of mediators from mast cells (Cox, 1967). Allergen exposure may secondarily increase non-specific bronchial reactivity to inhaled histamine, and Altounyan (1970) has shown that when sodium cromoglycate is used regularly in relation to allergen exposure it may prevent or reverse this increase.

We were unable to show any protective effect of ascorbic acid. However, Zuskin et al. (1973) have demonstrated a significant protective effect of ascorbic acid against histamine inhalations in normal individuals using more sensitive maximal expiratory flow volume curves. The protection they observed, however, was very small in comparison with the degree of protection produced by various medications in the present study.

We thank the patients for their co-operation, Buehringer Ingelheim Ltd. for supplying the Sch1000, Dr. C. Dunnett and Dr. M. Gent for statistical advice, Dr. Norman L. Jones and Dr. Jerry Dolovich for reviewing the manuscript, and Mrs. Elsie Siminoski, Mrs. Nancy Alder, and Miss Marilyn Cuff for help in the preparation of the manuscript.
The study was supported by the Ontario Thoracic Society and Fisons Pharmaceuticals Ltd.

Dr. Cockcroft is a Fellow of the Medical Research Council of Canada.

\section{References}

Altounyan, R. E. C. (1964). Variation of drug action $\overrightarrow{0}$ on airway obstruction in man. Thorax, 19, 406-415. Altounyan, R. E. C. (1970). Changes in histamine and $\vec{\omega}$ atropine responsiveness as a guide to diagnosis and evaluation of therapy in obstructive airways disease. $\overrightarrow{\vec{x}}$ In Disodium Cromoglycate in Allergic Airways Disease, edited by J. Pepys and A. W. Frankland, p. 47. Butterworths, London.

Altounyan, R. E. C. (1971). In discussion in: Identi- 䒿 fication of Asthma (Ciba Foundation Study Group, No. 38), edited by R. Porter and J. Birch, p. 160. Churchill Livingston, Edinburgh and London.

Altounyan, R. E. C. (1975). Clinical significance of cholinergic receptors in asthma. In: Allergy, '74, edited by M. A. Ganderton and A. W. Frankland, $\stackrel{\infty}{\oplus}$ p. 121. Pitman Medical Publications, London.

Anderson, S. D., Seale, J. P., Rozea, P., Bandler, L., Theobald, G., and Lindsay, D. A. (1976). Inhaled and oral salbutamol in exercise-induced asthma. American Review of Respiratory Disease, 114, 493500.

Benson, M. K. (1975). Bronchial hyperreactivity. British Journal of Diseases of the Chest, 69, 227239.

Booij-Noord, H., de Vries, K., Sluiter, H. J., and $\overrightarrow{\overrightarrow{0}}$ Orie, N. G. M. (1972). Late bronchial obstructive 3 reaction to experimental inhalation of house dust extract. Clinical Allergy, 2, 43-61.

Ciba Foundation Guest Symposium (1959). Terminology, definitions and classification of chronic 0 pulmonary emphysema and related conditions. Thorax, 14, 286-299.

Cox, J. S. G. (1967). Disodium cromoglycate (FPL 670) ('Intal'): a specific inhibitor of reaginic antibody-antigen mechanisms. Nature, 216, 1328-응 1329.

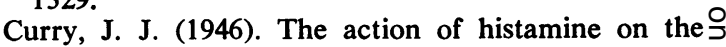
respiratory tract in normal and asthmatic subjects. $)$ Journal of Clinical Investigation, 25, 785-791.

Dubois, A. B., and Dautrebande, L. (1958). Acute effects of breathing inert dust particles and of car-o bachol aerosol on the mechanical characteristics of $N$ the lungs in man. Changes in response after inhal-N ing sympathomimetic aerosols. Journal of Clinical ${ }_{\sigma}^{\omega}$ Investigation, 37, 1746-1755.

Fillenz, M., and Woods, R. I. (1970). Sensory innervation of the airways. Ciba Foundation Symposium: Breathing, edited by R. Porter, pp. 101-109.? Churchill, London.

Godfrey, S., and König, P. (1976). Inhibition of exercise-induced asthma by different pharma- $\mathbb{D}$ cological pathways. Thorax, 31, 137-143.

Harnett, J., and Spector, S. L. (1976). Blocking effect $\frac{\mathbb{Q}}{\square}$ of SCH 1000, isoproterenol, and the combination on 
methacholine and histamine inhalations (Abstract). Journal of Allergy and Clinical Immunology, 57, 261.

Itkin, I. H., and Anand, S. C. (1970). The role of atropine as a mediator blocker of induced bronchial obstruction. Journal of Allergy, 45, 178-186.

Kershnar, H., Katz, R., Tashkin, D., Rachelefsky, G., and Siegel, S. (1976). Comparison of cromolyn sodium (CS), aerosolized atropine (A), isoproterenol (I), and $A+I$ in the prevention of exercise-induced asthma (EIA) (Abstract). Journal of Allergy and Clinical Immunology, 57, 261.

Kersten, W. (1974). Protektive Wirkung von Ipratropium-bromid (Sch1000) bei akuten Bronchokonstriktionen durch Allergeninhalation. Respiration, 31, 412-417.

Kiechel, F., Pollack, J., Cooper, D., and Weinberger, M. (1976). The comparative efficacy of theophylline (T) and cromolyn (C) in suppressing exerciseinduced bronchospasm (EIB) (Abstract). Journal of Allergy and Clinical Immunology, 57, 250.

Killian, D., Cockcroft, D. W., Hargreave, F. E., and Dolovich, J. (1976). Factors in allergen-induced asthma: relevance of the intensity of the airways allergic reaction and non-specific bronchial reactivity. Clinical Allergy, 6, 219-225.

Laitinen, L. A. I. (1974). Histamine and methacholine challenge in the testing of bronchial reactivity. Scandinavian Journal of Respiratory Disease, Supplement, 86.

Lancet (1975). Non-allergic provocation of asthma. Lancet (Editorial), 2, 691-692.

Lavin, N., Rachelefsky, G. S., and Kaplan, S. A. (1976). An action of disodium cromoglycate: inhibition of cyclic 3', 5'-AMP phosphodiesterase. Journal of Allergy and Clinical Immunology, 57, 80-88.

McNeill, R. S., Nairn, J. R., Millar, J. S., and Ingram, C. G. (1966). Exercise-induced asthma. Quarterly Journal of Medicine, 35, 55-67.

Makino, S. (1966). Clinical significance of bronchial sensitivity to acetylcholine and histamine in bronchial asthma. Journal of Allergy, 38, 127-142.

Mills, J. E., Sellick, H., and Widdicombe, J. G. (1970). Epithelial irritant receptors in the lungs. Ciba Foundation Symposium: Breathing, edited by R. Porter, p. 77-92. Churchill, London.

Nadel, J. A., Salem, H., Tamplin, B., and Tokiwa, Y. (1965). Mechanism of bronchoconstriction during inhalation of sulfur dioxide. Journal of Applied Physiology, 20, 164-167.

Orehek, J., and Gayrard, P. (1976). Les testes de provocation bronchique non-spécifique dans l'asthme. Bulletin Européen Physiopathologie Respiratoire, 12, 565.

Patel, K. R., Kerr, J. W., MacDonald, E. B., and MacKenzie, A. M. (1976). The effect of thymoxamine and cromolyn sodium on postexercise bronchoconstriction in asthma. Journal of Allergy and Clinical Immunology, 57, 285-292.

Pepys, J., Hargreave, F. E., Chan, M., and McCarthy, D. S. (1968). Inhibitory effects of disodium cromoglycate on allergen-inhalation tests. Lancet, 2, 134137.

Rosenthal, R. R., Summer, W. R., Permutt, S., and Norman, P. S. (1974). Effect of atropine on antigenmediated bronchospasm (Abstract). Journal of Allergy and Clinical Immunology, 53, 73.

Ryo, U. Y., Kang, B., and Townley, R. G. (1971). Effect of disodium chromoglycate on inhalation challenge with allergen histamine, and methacholine in subjects with bronchial asthma (Abstract). Journal of Allergy and Clinical Immunology, 47, 96.

Schack, J. A., and Waxler, S. H. (1949). An ultraviolet spectrophotometric method for the determination of theophylline and theobromine in blood and tissues. Journal of Pharmacology and Experimental Therapeutics, 97, 283-291.

Sellick, H., and Widdicombe, J. G. (1971). Stimulation of lung irritant receptors by cigarette smoke, carbon dust, and histamine aerosol. Journal of Applied Physiology, 31, 15-19.

Simonsson, B. G., Jacobs, F. M., and Nadel, J. A. (1967). Role of autonomic nervous system and the cough reflex in the increased responsiveness of airways in patients with obstructive airway disease. Journal of Clinical Investigation, 46, 1812-1818.

Townley, R. G., Kang, B., Lee, C. K., and Kolotkin, B. (1973). Effects of disodium chromoglycate on the intravenous infusion of histamine in asthmatics (Abstract). Journal of Allergy and Clinical Immunology, 51, 121-122.

Wells, R. E., Jr., Walker, J. E. C., and Hickler, R. B. (1960). Effects of cold air on respiratory airflow resistance in patients with respiratory-tract disease. New England Journal of Medicine, 263, 268-273.

Zuskin, E., Lewis, A. J., and Bouhuys, A. (1973). Inhibition of histamine-induced airway constriction by ascorbic acid. Journal of Allergy and Clinical Immunology, 51, 218-226.

Requests for reprints to: Dr. Frederick E. Hargreave, St. Joseph's Hospital, Hamilton, Ontario, Canada. 